\title{
The progress of targeted therapy in advanced gastric cancer
}

\author{
Miao-zhen Qiu and Rui-hua Xu*
}

\begin{abstract}
Although palliative chemotherapy has been shown to prolong survival and improve quality of life, the survival of advanced gastric cancer (AGC) patients remains poor. With the advent of targeted therapy, many molecular targeted agents have been evaluated in clinical studies. Trastuzumab, an anti-HER2 monoclonal antibody, has shown activity against HER2-positive AGC and becomes the first targeted agent approved in AGC. Drugs that target epidermal growth factor receptor, including monoclonal antibody and tyrosine kinase inhibitor, do not bring survival benefit to patients with AGC. Additionally, vascular endothelial growth factor inhibitors are also under investigation. Ramucirumab has shown promising result. Other targeted agents are in preclinical or early clinical development, such as mammalian target of rapamycinm inhibitors and c-MET inhibitors.
\end{abstract}

\section{Introduction}

Approximately one million people are diagnosed each year with gastric cancer, making it the fourth most common cancer and the second leading cause of cancer related death worldwide with an estimated 800,000 deaths caused by the disease [1]. The incidence of gastric cancer varies widely according to geographic region and is particularly common in eastern Asia [2]. According to the 2012 Chinese cancer registry annual report, gastric cancer is the third most common cancer and the second leading cause of cancer related death in China [3]. The only treatment that offers a potential cure is complete resection of the tumor. However, in most of countries, the majority of patients are diagnosed at advanced stages and have a poor prognosis. Though first-line chemotherapy for advanced gastric cancer (AGC) prolongs overall survival (OS) and improves quality of life compared with best supportive care (BSC). The median survival of advanced gastric cancer patients who received palliative chemotherapy is approximately 7 to 11 months [4-8]. In 2010, trastuzumab (Herceptin, Roche, Basel, Switzerland), a recombinant humanized monoclonal antibody that targets human epidermal growth factor receptor-2 (HER2), had already been confirmed to be

\footnotetext{
* Correspondence: xurh@sysucc.org.cn

Department of Medical Oncology, Sun Yat-Sen University Cancer Center, State Key Laboratory of Oncology in South China, Collaborative Innovation Center for Cancer Medicine, 651 Dong Feng Road East, Guangzhou 510060, China
}

\section{Biomed Central}

(c) 2013 Qiu and Xu; licensee BioMed Central Ltd. This is an open access article distributed under the terms of the Creative Commons Attribution License (http://creativecommons.org/licenses/by/2.0), which permits unrestricted use, distribution, and reproduction in any medium, provided the original work is properly cited. effective when combined with chemotherapy in HER2positive AGC patients [9]. Trastuzumab is the first targeted agent that gets the indication in AGC, but it is not the only targeted agents which have tried their applications in AGC. The other therapeutic strategies include: epidermal growth factor receptor (EGFR) inhibitors, vascular endothelial growth factor (VEGF) inhibitors, hepatocyte growth factor (HGF) and its receptor c-MET pathway inhibitor, mammalian target of rapamycinm (m-TOR) inhibitor et al. This review will focus on the recent progress in targeted agents for the treatment of AGC (Table 1).

\section{EGFR-signaling pathway}

EGFR exists on the cell surface and is part of the family of TK receptor including HER2. EGFR overexpression has been reported in approximately $30 \%$ to $50 \%$ of gastric cancers and is associated with poor prognosis [10-14].

\section{Anti-HER2 monoclonal antibodys}

HER2, a transmembrane tyrosine kinase (TK) receptor, is the preferred heterodimerization partner of the other HER family members (HER1 or EGFR, HER3 and HER4). The HER2-HER3 heterodimer plays a critical role in oncogenic transformation in HER2-driven tumors $[15,16]$. In breast cancer, amplification and overexpression of the HER2 gene is associated with poor outcomes, higher mortality, and higher recurrence as well as 
Table 1 Available targeted agents in advanced gastric cancer

\begin{tabular}{|c|c|c|c|c|c|c|c|c|}
\hline NCT code/trial name & Drugs & & Setting & Masking & Primary endpoint & Arm & Status & Results \\
\hline $\begin{array}{l}\text { PhasellIToGA/ } \\
\text { NCT01041404 }\end{array}$ & $\begin{array}{l}\text { HER2 } \\
\text { inhibitor }\end{array}$ & Trastuzumab & First line & $\begin{array}{l}\text { Double } \\
\text { blind }\end{array}$ & OS & Cisplatin + fluoropyrimidine + Trastuzumab vs. Placebo & Finished & Positive \\
\hline PhasellINCT01774786 & & Pertuzumab & First line & $\begin{array}{l}\text { Double } \\
\text { blind }\end{array}$ & OS & $\begin{array}{l}\text { Trastuzumab + cisplatin + fluoropyrimidine + Pertuzumab } \\
\text { vs. Placebo }\end{array}$ & Ongoing & Unknown \\
\hline Phase III/IIINCT01641939 & & T-DM1 & Second line & $\begin{array}{l}\text { Open } \\
\text { label }\end{array}$ & OS & T-DM1 vs. Taxane & Ongoing & Unknown \\
\hline $\begin{array}{l}\text { Phasell TYTAN/ } \\
\text { NCT00486954 }\end{array}$ & & Lapatinib & Second line & $\begin{array}{l}\text { Open } \\
\text { label }\end{array}$ & OS & Lapatinib vs. Paclitaxel & Finished & Negative \\
\hline $\begin{array}{l}\text { Phaselll LOGiC/ } \\
\text { NCT00680901 }\end{array}$ & & Lapatinib & First line & $\begin{array}{l}\text { Double } \\
\text { blind }\end{array}$ & OS & Capecitabine + oxaliplatin + Lapatinib vs. Placebo & Finished & Negative \\
\hline $\begin{array}{l}\text { PhasellIEXPAND/ } \\
\text { NCT00678535 }\end{array}$ & $\begin{array}{l}\text { EGFR } \\
\text { Inhibitors }\end{array}$ & Cetuximab & First line & $\begin{array}{l}\text { Open } \\
\text { label }\end{array}$ & PFS & Capecitabine and cisplatin + Cetuximab vs. Placebo & Finished & Negative \\
\hline $\begin{array}{l}\text { PhasellIREAL-3/ } \\
\text { NCT01234324 }\end{array}$ & & Panitumumab & First line & $\begin{array}{l}\text { Open } \\
\text { label }\end{array}$ & $\begin{array}{l}\text { Frequency of } \mathrm{pT} 3 / \mathrm{T} 4 \\
\text { categories after surgery }\end{array}$ & EOX (epirubicin/oxaliplatin/capecitabine) & Ongoing & Unknown \\
\hline $\begin{array}{l}\text { Phaselll AVAGAST/ } \\
\text { NCT00548548 }\end{array}$ & $\begin{array}{l}\text { VEGF } \\
\text { inhibitors }\end{array}$ & Bevacizumab & First line & $\begin{array}{l}\text { Double } \\
\text { blind }\end{array}$ & OS & Capecitabine + cisplatin + Bevacizumab vs. Placebo & Finished & Negative \\
\hline $\begin{array}{l}\text { Phaselll REGARD/ } \\
\text { NCT00917384 }\end{array}$ & & Ramucirumab & Second line & $\begin{array}{l}\text { Double } \\
\text { blind }\end{array}$ & OS & and BSC + Ramucirumab vs. Placebo & Finished & Positive \\
\hline $\begin{array}{l}\text { PhaselllRAINBOW/ } \\
\text { NCT01170663 }\end{array}$ & & Ramucirumab & Second line & $\begin{array}{l}\text { Double } \\
\text { blind }\end{array}$ & OS & Paclitaxel + Ramucirumab vs. Placebo & Ongoing & Unknown \\
\hline PhasellINCT01246960 & & Ramucirumab & First line & $\begin{array}{l}\text { Double } \\
\text { blind }\end{array}$ & PFS & mFOLFOX6+ Ramucirumab vs. Placebo & Ongoing & Unknown \\
\hline PhasellINCT00970138 & & Apatinib & Third line & $\begin{array}{l}\text { Double } \\
\text { blind }\end{array}$ & PFS & Placebo vs.Apatinib & Finishes & Positive \\
\hline PhasellINCT01512745 & & Apatinib & Third line & $\begin{array}{l}\text { Double } \\
\text { blind }\end{array}$ & PFS & placebo vs. apatinib & Ongoing & Unknown \\
\hline PhasellINCT01747551 & & Aflibercept & First line & $\begin{array}{l}\text { Double } \\
\text { blind }\end{array}$ & PFS & mFOLFOX6 + Aflibercept vs. Placebo & Ongoing & Unknown \\
\hline PhasellINCT01152645 & $\begin{array}{l}\text { c-MET } \\
\text { inhibitor }\end{array}$ & $\begin{array}{l}\text { Tivantinib (ARQ } \\
\text { 197) }\end{array}$ & $\begin{array}{l}\text { Second/ } \\
\text { Thirdline }\end{array}$ & $\begin{array}{l}\text { Open } \\
\text { label }\end{array}$ & DCR & Tivantinib & Finished & $\begin{array}{l}\text { Modest } \\
\text { efficacy }\end{array}$ \\
\hline PhasellINCT01662869 & & Onartuzumab & First line & $\begin{array}{l}\text { Double } \\
\text { blind }\end{array}$ & OS & mFOLFOX6 + Onartuzumab vs. Placebo & Ongoing & Unknown \\
\hline $\begin{array}{l}\text { PhasellIGRANITE-1/ } \\
\text { NCT00879333 }\end{array}$ & $\begin{array}{l}\text { m-TOR } \\
\text { inhibitor }\end{array}$ & $\begin{array}{l}\text { Everolimus } \\
\text { (RAD001) }\end{array}$ & $\begin{array}{l}\text { Second/third } \\
\text { line }\end{array}$ & $\begin{array}{l}\text { Double } \\
\text { blind }\end{array}$ & OS & Everolimus vs. Placebo & Finished & Negative \\
\hline
\end{tabular}

Abbreviation: HER2 human epidermal growth factor receptor-2, OS overall survival, EGFR epidermal growth factor receptor, PFS progression free survival, VEGF vascular endothelial growth factor, BSC best supportive care, $D C R$ disease control rate, $m$-TOR mammalian target of rapamycinm. 
metastasis rate [17-19]. However, the association between HER2 status and prognosis in gastric cancer remains controversial. In a few studies a correlation between HER2 amplification or overexpression and favorable survival was shown $[20,21]$. In a retrospective analysis from four Chinese clinical centers, the HER2 status of 726 gastric cancer patients with all stages was detected. They found that HER2 was not a prognostic factor for gastric cancer patients [22]. A systematic analysis of data from the literature indicated that there was a clear trend towards a potential role for HER2 as a negative prognostic factor in gastric cancer patients [23].

\section{Trastuzumab}

In the ToGA trial, the addition of trastuzumab to chemotherapy significantly improved OS compared with chemotherapy alone in patients with HER2-positive AGC. The HER2 positive rate was $22.1 \%$ in this study. The median OS was improved significantly in the trastuzumab arm compared with the control arm [13.5 vs. 11.1 months, $\mathrm{P}=0.0048$; hazard ratio (HR), $0.74 ; 95 \%$ confidence interval (CI), 0.60 to 0.91 ]. In subgroup analysis, the patients with HER2 immunohistochemistry (IHC) 2+/fluorescence in situ hybridization + or IHC 3+ had a longer OS compared with the chemotherapyalone arm (16 months vs. 11.8 months). Moreover, the addition of trastuzumab to chemotherapy in the ToGA trial was well-tolerated, with no differences in the incidence of grade 3 or 4 adverse events (AEs) between the two groups [9]. Based on the result of ToGA study, trastuzumab with chemotherapy was recommended for HER2 overexpressing AGC (category 1 for combination with cisplatin and fluoropyrimidine; category $2 \mathrm{~B}$ for combination with other chemotherapy agents; not recommended for use with anthracyclines) in the national comprehensive cancer network guidelines of gastric cancer version 22012 .

\section{Pertuzumab}

Pertuzumab is a monoclonal antibody that prevents dimerization of HER2 with other HER family receptors [24]. Its efficacy in combination with trastuzumab in HER2-positive metastatic breast cancer patients has been demonstrated in phase III clinical trials [25,26]. At the 2013 American Society of clinical oncology (ASCO) meeting, the result of an international phase III study was reported. This was a double-blind, placebocontrolled, randomized phase III study and it was designed to evaluate efficacy and safety of pertuzumab + trastuzumab + chemotherapy in patients with HER2positive metastatic gastric or gastroesophageal junction (GEJ) cancer. In this study, HER2-positive metastatic gastric cancer patients were randomized 1:1 to receive trastuzumab + cisplatin + fluoropyrimidine + pertuzumab vs. placebo . Primary endpoint was OS. The result of this study is worth looking forward to [27].

\section{T-DM1}

T-DM1 is an antibody-drug conjugate in which trastuzumab is conjugated to a cytotoxic compound, emtansine [28]. Upon binding of the trastuzumab moiety to HER2, T-DM1 is internalized into the tumor cell, releasing the DM1 moiety, which inhibits microtubules. A trial (NCT01641939) is now ongoing to examine the efficacy and safety of T-DM1 compared with standard taxane therapy in patients with HER2-positive gastric cancer in second line setting. In this study, patients will be randomized to one of the three groups, $3.6 \mathrm{mg} / \mathrm{kg}$ T-DM1 every 3 weeks, $2.4 \mathrm{mg} / \mathrm{kg}$ T-DM1 every week, or standard taxane therapy (Taxol $80 \mathrm{mg} / \mathrm{m}^{2} / \mathrm{wk}$ or docetaxol $75 \mathrm{mg} / \mathrm{m}^{2} \mathrm{q} 3 \mathrm{wk}$ ), for at least four cycles (12 weeks). Planned endpoints include OS.

The results of these studies are eagerly awaited to examine the efficacy of this approach in patients with HER2-positive AGC.

\section{HER-2 TKI}

Lapatinib, a reversible dual TKI that affects both HER2 and EGFR, has also been clinically shown to be active against HER2-positive breast cancer as a monotherapy and in combination with capecitabine [29]. The TYTAN study compared lapatinib and paclitaxel with paclitaxel alone in patients with HER2-positive metastatic gastric cancer in a second line setting. The primary endpoint of the study was OS. Though lapatinib showed efficacy in HER2 IHC 3+ subgroups, this study did not show an improvement in OS. These results indicated that the definition of HER2-positive AGC was very important for the development of new anti-HER2 agents [30]. At the 2013 ASCO meeting, lapatinib in combination with capecitabine plus oxaliplatin in HER2-positive advanced or metastatic gastroesophageal adenocarcinoma, the LOGiC trial was reported. Primary endpoint of improving OS was not met. The median OS in the lapatinib group and the control group was 12.2 months and 10.5 months, respectively, $\mathrm{P}=0.3492$. Improved OS was seen in Asian patients and patients under 60 years old. Secondary efficacy endpoints of progression free survival (PFS), response rate (RR) and duration of response were improved with addition of lapatinib. No new safety signal was identified, but increased toxicity was seen with the addition of lapatinib to capecitabine and oxaliplatin, particularly diarrhea and skin toxicity [31]. Prior to this study, there was no evidence to support the use of lapatinib in HER2-positive AGC. 


\section{Cetuximab}

Manageable and expected safety profiles with substantial activities were reported in phase II studies of cetuximab plus various first line chemotherapy regimens in patients with AGC [32-35].

In a prospective multi-center biomarker-oriented phase III trial using cetuximab with folfiri as first-line treatment in AGC, patients received weekly cetuximab $\left(400 \mathrm{mg} / \mathrm{m}^{2}\right.$ on day 1 , subsequently $250 \mathrm{mg} / \mathrm{m}^{2}$ ) plus irinotecan and a 24-hour continuous infusion of folinic acid and 5-fu on days 1, 8, 15, 22, 29 and 36 of a 50-day cycle, until disease progress (PD). In 48 assessable patients, the overall response rate was $46 \%$ and disease control rate (DCR) was 79\%. Median PFS and OS were 9.0 months (95\% CI 7.1-15.6) and 16.5 months (95\% CI 11.7-30.1), respectively. No obvious cetuximab-related side effects were recorded in this study. However, despite a favorable result in these phase II trials, the results of a randomized phase III trial comparing cetuximab in combination with capecitabine and cisplatin with chemotherapy alone (EXPAND) were negative. In this study, 904 patients were randomly assigned (1:1) to receive first-line chemotherapy (capecitabine and cisplatin) with or without cetuximab $\left(400 \mathrm{mg} / \mathrm{m}^{2}\right.$ on day 1 , subsequently $250 \mathrm{mg} / \mathrm{m}^{2}$ ). The primary endpoint was PFS. The median PFS and OS were 4.4 and 9.4 months, respectively, in patients assigned to cetuximab plus chemotherapy compared with 5.6 and 10.7 months in patients receiving chemotherapy, respectively (PFS, $\mathrm{p}=0.3158 ; \mathrm{OS}, \mathrm{p}=0.9547$ ) [36]. Addition of cetuximab provided no additional benefit to chemotherapy alone in the first-line treatment of advanced gastric cancer.

\section{Panitumumab}

Panitumumab is a fully human, immunoglobulin G2 monoclonal antibody directed against the EGFR. In metastatic colorectal cancer, panitumumab has monotherapy activity in patients with chemotherapy refractory diseases and, when added to chemotherapy, can improve PFS in Kirsten-ras (KRAS) oncogene wide type patients in the first line and second line settings.

The REAL-3 trial was designed to compare combination chemotherapy (epirubicin/oxaliplatin/capecitabine, EOX regimen) with or without panitumumab in 553 patients with advanced esophagogastric adenocarcinoma at 63 centers. Median OS in 275 patients allocated to EOX was 11.3 months (95\% CI 9.6-13.0) compared with 8.8 months (95\% CI 7.7-9.8) in 278 patients allocated panitumumab group (HR 1.37, 95\% CI 1.07-1.76; $\mathrm{P}=0.013)$. Panitumumab group was associated with increased incidence of grade 3-4 diarrhoea, rash, mucositis and hypomagnesaemia but reduced incidence of haematological toxicity [37].

Based on the results above, no more clinical trials of anti-EGFR monoclonal antibody in gastric cancer will be carried out. Moreover, neither erlotinib nor gefitinib showed activity in anti-gastric cancer in phase III studies.

\section{VEGF-signaling pathway}

Tumor angiogenesis and metastasis are strongly linked with angiogenesis in most solid tumors. VEGF is a key mediator of physiologic and pathologic angiogenesis [38].

\section{Anti-VEGF monoclonal antibody}

Preclinical studies showed that bevacizumab (Avastin, Genentech/Roche, San Francisco, CA/Basel, Switzerland), a monoclonal antibody targeting VEGF-A, resulted in tumor growth inhibition when given as monotherapy or in combination with cytotoxic agents [39]. In patients with gastric cancer, VEGF expression has been linked to tumor aggressiveness and poor prognosis [14,40-42]. Several phase II trials combining bevacizumab with different chemotherapeutic compounds were conducted on treatment-naïve or pretreated patients with AGC or GEJ cancers [43-45]. AVAGAST was a prospective, randomassignment, double-blind, placebo-controlled phase III clinical trial comparing capecitabine/cisplatin with or without bevacizumab as first-line therapy in 774 patients with AGC [46]. The primary endpoint was OS. Although AVAGAST did not reach its primary endpoint (OS: 12.1 vs. 10.1 months for the bevacizumab and placebo groups (HR, 0.87; $\mathrm{P}=0.1002)$ ), both median PFS (6.7 v 5.3 months; HR, 0.80; 95\% CI, 0.68 to $0.93 ; \mathrm{P}=0.0037$ ) and RR (46.0\% v 37.4\%; P = 0.0315) were significantly improved with bevacizumab versus placebo. The incidence of grades 3 to 4 AEs potentially related to bevacizumab was similar in both arms.

\section{Anti-VEGFR monoclonal antibody}

Ramucirumab (IMC-1121B; Im Clone Systems, New York, $\mathrm{NY}$ ) is a fully human immunoglobulin G1 monoclonal antibody that binds with high affinity to the extracellular VEGF-binding domain of VEGFR-2. Phase I clinical trials demonstrated its objective antitumor activity and antiangiogenic effects over a wide range of dose levels, suggesting that ramucirumab may have a favorable therapeutic index in treating malignancies amenable to VEGFR-2 inhibition [47].

REGARD study [48] is a phase III, randomized, double-blinded trial of ramucirumab in the treatment of AGC or GEJ adenocarcinoma in second line setting. Patients were randomized 2:1 to receive ramucirumab (8 $\mathrm{mg} / \mathrm{kg} \mathrm{IV)} \mathrm{plus} \mathrm{BSC} \mathrm{or} \mathrm{placebo} \mathrm{plus} \mathrm{BSC} \mathrm{every} 2$ weeks until PD, unacceptable toxicity, or death. The primary endpoint was OS. The HR for OS was 0.776 (95\% CI, 0.603-0.998; P = 0.0473). Median OS was 5.2 months for ramucirumab group and 3.8 months for placebo group. The HR for PFS was 0.483 (95\% CI, 0.376-0.620; $\mathrm{p}<0.0001)$. Median PFS was 2.1 and 1.3 
months, 12 -weeks PFS was $40 \%$ and $16 \%$, ORR was $3.4 \%$ and $2.6 \%$ for ramucirumab and placebo groups respectively. The most frequent grade $\geq 3$ AEs were: hypertension, anemia, abdominal pain, ascites and fatigue. Ramucirumab conferred a statistically significant benefit in OS and PFS compared to placebo in AGC in the second line setting with an acceptable safety profile. The phase III trial RAINBOW is a randomized multicenter double-blind, placebo controlled trial evaluating the safety and efficacy of paclitaxel plus ramucirumab drug product compared to paclitaxel plus placebo. This study is still on-going. Another randomized phase II clinical trial of mFOLFOX6 plus ramucirumab vs. placebo for AGC is also ongoing (Table 1).

\section{VEGFR TKI}

Apatinib (YN968D1) is a small-molecular TKI agent targeting at VEGFR [49]. In a randomized, double-blind, multicenter, phase II, three-arm, placebo-control study of apatinib in patients with metastatic gastric carcinoma, patients were randomized to receive placebo or apatinib (placebo vs. apatinib at $850 \mathrm{mg}$ once a day vs. $425 \mathrm{mg}$ twice a day) [50]. The primary endpoint was PFS. The respective survival rates were as follows: median PFS, 1.4 months vs. 3.4 months vs. 3.4 months; median OS, 2.5 months vs. 4.8 months vs. 4.3 months. Common AEs included hypertension and hand-foot syndrome. Based on this result, a randomized, double blinded, placebo controlled multicenter phase III study in a third-line setting in AGC is currently being conducted in China. Patients are scheduled to receive apatinib $850 \mathrm{mg}$ qd or placebo until PD or intolerable toxicity or patients' withdrawal of consent. The primary endpoint is PFS (NCT01512745).

\section{VEGF trap}

Aflibercept (VEGF Trap, Sanofi, Paris France; and Regeneron, Tarrytown, NY, USA) is a recombinant fusion protein consisting of extracellular domains of the human VEGFR fused to the Fc portion of human immunoglobulin G1 [51-53]. Its biological affinity for VEGF is reported to be significantly higher than that of bevacizumab [54]; however, there are no preclinical data to suggest its increased efficacy in AGC.

Aflibercept has recently been approved by the Food and Drug Administration for patients with treatmentresistant colorectal cancer. A phase II clinical trial to test the safety and effectiveness of aflibercept in combination with mFOLFOX6 compared to mFOLFOX6 alone in patients with AGC is ongoing.

\section{Other targeted agents MET inhibitor}

c-Met is a proto-oncogene that encodes a protein known as hepatocyte growth factor receptor (HGFR) [55,56]. It stimulates cell scattering, invasion, protection from apoptosis and angiogenesis [57]. Upon HGF stimulation, MET induces MET kinase catalytic activity which triggers transphosphorylation of the tyrosine (Tyr) 1234 and Tyr 1235, thus initiating a whole spectrum of biological activities driven by MET. A high level of c-Met expression has been correlated with poor survival in patients with gastric cancer [58].

c-Met inhibitors include monoclonal antibodies and small molecules that inhibit the enzymatic activity of the c-Met TK. There are basically two classes of c-Met inhibitors, ATP competitive and ATP non-competitive inhibitor. ATP competitive inhibitors are further divided into two classes; class I (SU-11274-like) and class II (AM7-like) on the basis of different types of binding and a third group of noncompetitive ATP inhibitor that binds in a different way to the other two $[59,60]$.

Elevated expressions of c-MET and its ligand, HGF, have been frequently found in gastric cancer, and are associated with a more aggressive disease $[61,62]$. Tivantinib is a selective, non-ATP competitive, small-molecule inhibitor of c-MET and is under development in several cancers. In a single-arm phase II study, the efficacy of tivantinib monotherapy in Asian patients with previously treated AGC was evaluated [63]. Tivantinib was daily administered $360 \mathrm{mg}$ bid orally. The primary endpoint was DCR. No objective response was observed, and DCR was $36.7 \%$ (11/30 patients). Median PFS was 43 (95\% CI: 29.0-92.0) days. There is no treatment-related death and novel safety concern. Tivantinib as a monotherapy showed a modest efficacy in previously treated AGC, and further trial testing in combination would be warranted in AGC.

Onartuzumab is a humanized $\mathrm{mAb}$ directed against HGFR. A randomized, phase III, multicenter, doubleblind, placebo-controlled study evaluating the efficacy and safety of onartuzumab in combination with mFOLFOX6 in patients with metastatic Her2-negative, c-Metpositive gastroesophageal cancer is now ongoing.

\section{m-TOR inhibitor}

mTOR is a key protein kinase that regulates cell growth and proliferation, cellular metabolism and angiogenesis [64]. Mutations in these components result in inappropriate mTOR activation [64]. The mTOR pathway has been shown to be frequently dysregulated in a variety of human cancers, including gastric cancer [65]. Overexpression of the mTOR downstream effectors eIF4E and 4E binding protein 1 (4E-BP1) was shown in GI cancer cells [64]. Everolimus (RAD001) is an oral inhibitor of $\mathrm{m}$-TOR, which is downstream of the Akt pathway. Everolimus reduced 4E-BP1 phosphorylation and attenuated production of the proangiogenic factors hypoxiainducible factor and VEGF in these gastric cancer cell 
lines [65]. Everolimus has demonstrated antitumor activity in gastric cancer in preclinical studies [64-66] and a phase I study involving patients with AGC [67]. The results of a phase IIstudy of everolimus in 53 patients with previously treated AGC showed a disease control rate of $56.0 \%$ and median PFS of 2.7 months. At a median follow-up duration of 9.6 months, the median OS was 10.1 months and good tolerability was observed [68]. Based on this promising result, a prospective phase III trial of everolimus in previously treated patients with advanced gastric cancer: GRANITE-1 was conducted [69]. A total of 656 patients from 23 countries were enrolled; 439 were randomized to everolimus, 217 to placebo. Median OS was 5.39 months with everolimus vs 4.34 months with placebo (HR, 0.90; 95\% CI, 0.75-1.08; $\mathrm{P}=0.1244)$. Median PFS was 1.68 vs 1.41 months (HR, 0.66; 95\% CI, 0.56-0.78; p < 0.0001). The most common grade $3 / 4$ adverse events were anemia, decreased appetite and fatigue. Everolimus monotherapy did not significantly improve OS in patients with AGC previously treated with 1 or 2 lines of systemic chemotherapy.

\section{Future perspectives}

Emerging data from the development of targeted therapy have provided novel strategies that are expected to translate into survival benefits for AGC patients. The results of the ToGA study recently demonstrated that the addition of trastuzumab to chemotherapy can bring survival benefit to HER2-positive AGC patients. However, this benefit is limited to only 20\% of AGC patients (HER2-positive). Therefore, there remains a critical need for both the development of more effective agents and the identification of predictive molecular markers to select those patients who might benefit most from specific targeted therapies. Till now both cetuximab and bevacizumab have failed in phase III trail for AGC. The results of pertuzumab and T-DM1 are worth waiting for. The other promising targeted agents include: ramucirumab, aflibercept and apatinib as well as c-MET inhibitors.

\footnotetext{
Abbreviations

AGC: Advanced gastric cancer; OS: Overall survival; BSC: Best supportive care; HER2: Human epidermal growth factor receptor-2; EGFR: Epidermal growth factor receptor; VEGF: Vascular endothelial growth factor; HGF: Hepatocyte growth factor; mTOR: Mammalian target of rapamycinm; TK: Tyrosine kinase; HR: Hazard ratio; Cl: Confidence interval; IHC: Immunohistochemistry; AEs: Adverse events; GEJ: Gastroesophageal junction; OS: Overall survival; PFS: Progression free survival; ASCO: American Society of clinical oncology; PFS: Progression free survival; RR: Response rate; PD: Disease progress; DCR: Disease control rate; KRAS: Kirsten-ras; HGFR: Hepatocyte growth factor receptor; Tyr: Tyrosine.
}

\section{Competing interests}

The authors declare that they have no competing interests.

\section{Authors' contributions}

All authors have contributed to data preparation, drafting and revising the manuscripts. Both authors have read and approved the final manuscript.

Received: 27 August 2013 Accepted: 2 December 2013

Published: 11 December 2013

\section{References}

1. Kamangar F, Dores GM, Anderson WF: Patterns of cancer incidence, mortality, and prevalence across five continents: defining priorities to reduce cancer disparities in different geographic regions of the world. J Clin Oncol 2006, 24(14):2137-2150

2. Moore MA, Eser S, Igisinov N, Igisinov S, Mohagheghi MA, Mousavi-Jarrahi A Ozentürk G, Soipova M, Tuncer M, Sobue T: Cancer epidemiology and control in North-Western and Central Asia - past, present and future. Asian Pac J Cancer Prev 2010, 11(Supple 2):17-32.

3. Hao J, Chen WQ: Chinese cancer registry annual report. Beijing: Military Medical Science Press; 2012.

4. Murad AM, Santiago FF, Petroianu A, Rocha PR, Rodrigues MA, Rausch M: Modified therapy with 5-fluorouracil, doxorubicin, and methotrexate in advanced gastric cancer. Cancer 1993, 72(1):37-41.

5. Pyrhonen S, Kuitunen T, Nyandoto P, Kouri M: Randomised comparison of f luorouracil, epidoxorubicin and methotrexate (FEMTX) plus supportive care with supportive care alone in patients with non-resectable gastric cancer. Br J Cancer 1995, 71(3):587-591.

6. Cunningham D, Starling N, Rao S, Iveson T, Nicolson M, Coxon F, Middleton G, Daniel F, Oates J, Norman AR: Upper gastrointestinal clinical studies group of the national cancer research institute of the United Kingdom: capecitabine and oxaliplatin for advanced esophagogastric cancer. N Engl J Med 2008, 358(1):36-46.

7. Van Cutsem E, Moiseyenko VM, Tjulandin S, Majlis A, Constenla M, Boni C, Rodrigues A, Fodor M, Chao Y, Voznyi E, Risse ML, Ajani JA, V325 Study Group: Phase III study of docetaxel and cisplatin plus fluorouracil compared with cisplatin and fluorouracil as first-line therapy for advanced gastric cancer: a report of the V325 Study Group. J Clin Oncol 2006, 24(31):4991-4997.

8. Wagner AD, Grothe W, Haerting J, Kleber G, Grothey A, Fleig WE: Chemotherapy in advanced gastric cancer: a systematic review and meta-analysis based on aggregate data. J Clin Oncol 2006, 24(18):2903-2909.

9. Bang YJ, Van Cutsem E, Feyereislova A, Chung HC, Shen L, Sawaki A, Lordick F, Ohtsu A, Omuro Y, Satoh T, et al: Trastuzumab in combination with chemotherapy versus chemotherapy alone for treatment of HER2 positive advanced gastric or gastro-oesophageal junction cancer (ToGA): a phase 3, open-label, randomised controlled trial. Lancet 2010, 376(9742):687-697.

10. Wang KL, Wu TT, Choi IS, Wang H, Resetkova E, Correa AM, Hofstetter WL, Swisher SG, Ajani JA, Rashid A, et al: Expression of epidermal growth factor receptor in esophageal and esophagogastric junction adenocarcinomas: association with poor outcome. Cancer 2007, 109(4):658-667.

11. Langer $R$, Von Rahden BH, Nahrig J, Von Weyhern C, Reiter R, Feith M, Stein HJ, Siewert JR, Höfler H, Sarbia M: Prognostic significance of expression patterns of c-erbB-2, p53, p16INK4A, p27KIP1, cyclin D1 and epidermal growth factor receptor in oesophageal adenocarcinoma: a tissue microarray study. J Clin Pathol 2006, 59(6):631-634.

12. Kim MA, Lee HS, Lee HE, Jeon YK, Yang HK, Kim WH: EGFR in gastric carcinomas: prognostic significance of protein overexpression and high gene copy number. Histopathology 2008, 52(6):738-746.

13. Galizia G, Lieto E, Orditura M, Castellano P, Mura AL, Imperatore V, Pinto M, Zamboli A, De Vita F, Ferraraccio F: Epidermal growth factor receptor (EGFR) expression is associated with a worse prognosis in gastric cancer patients undergoing curative surgery. World J Surg 2007, 31(7):1458-1468.

14. Lieto E, Ferraraccio F, Orditura M, Castellano P, Mura AL, Pinto M, Zamboli A, De Vita F, Galizia G: Expression of vascular endothelial growth factor (VEGF) and epidermal growth factor receptor (EGFR) is an independent prognostic indicator of worse outcome in gastric cancer patients. Ann Surg Oncol 2008, 15(1):69-79.

15. Hsieh AC, Moasser MM: Targeting HER proteins in cancer therapy and the role of the non-target HER3. Br J Cancer 2007, 97(4):453-457. 
16. Lian L, Ning W, Jin L: Novel targeted agents for gastric cancer. J Hematol Oncol 2012, 5:31

17. Toikkanen S, Helin H, Isola J, Joensuu H: Prognostic significance of HER-2 oncoprotein expression in breast cancer: a 30-year follow-up. J Clin Oncol 1992, 10(7):1044-1048.

18. Seshadri R, Horsfall DJ, Firgaira F, McCaul K, Setlur V, Chalmers AH, Yeo R, Ingram D, Dawkins $H$, Hahnel $R$ : The relative prognostic significance of total cathepsin D and HER-2/neu oncogene amplification in breast cancer. The South Australian Breast Cancer Group. Int J Cancer 1994 56(1):61-65.

19. Slamon DJ, Clark GM, Wong SG, Levin WJ, Ullrich A, McGuire WL: Human breast cancer: correlation of relapse and survival with amplification of the Her-2/neu oncogene. Science 1987, 235(4785):177-182.

20. Jain S, Filipe MI, Gullick WJ, Linehan J, Morris RW: c-erbB-2 proto-oncogene expression and its relationship to survival in gastric carcinoma: an immunohistochemical study on archival material. Int J Cancer 1991, 48(5):668-671.

21. Gómez-Martin C, Garralda E, Echarri MJ, Ballesteros A, Arcediano A Rodríguez-Peralto JL, Hidalgo M, López-Ríos F: HER2/neu testing for anti-HER2-based therapies in patients with unresectable and/or metastatic gastric cancer. J Clin Pathol 2012, 65(8):751-757.

22. Sheng WQ, Huang D, Ying JM, Lu N, Wu HM, Liu YH, Liu JP, Bu H, Zhou XY Du X: HER2 status in gastric cancers: a retrospective analysis from four Chinese representative clinical centers and assessment of its prognostic significance. Ann Oncol 2013, 24(9):2360-2364.

23. Jørgensen JT, Hersom M: HER2 as a prognostic marker in gastric cancer a systematic analysis of data from the literature. J Cancer 2012, 3:137-144.

24. Pazo Cid RA, Antón A: Advanced HER2-positive gastric cancer: current and future targeted therapies. Crit Rev Oncol Hematol 2013, 85(3):350-362.

25. Baselga J, Gelmon KA, Verma S, Wardley A, Conte P, Miles D, Bianchi G, Cortes J, McNally VA, Ross GA, Fumoleau P, Gianni L: Phase II trial of pertuzumab and trastuzumab in patients with human epidermal growth factor receptor 2-positive metastatic breast cancer that progressed during prior trastuzumab therapy. J Clin Oncol 2010, 28(7):1138-1144.

26. Cortés J, Fumoleau P, Bianchi GV, Petrella TM, Gelmon K, Pivot X, Verma S, Albanell J, Conte P, Lluch A, et al: Pertuzumab monotherapy after trastuzumab-based treatment and subsequent reintroduction of trastuzumab: activity and tolerability in patients with advanced human epidermal growth factor receptor 2-positive breast cancer. J Clin Oncol 2012, 30(14):1594-1600.

27. Tabernero J, Hoff PM, Shen L, Ohtsu A, Yu R, Eng-Wong J, Kang YK: Pertuzumab (P) with trastuzumab (T) and chemotherapy (CTX) in patients (pts) with HER2-positive metastatic gastric or gastroesophageal junction (GEJ) cancer: An international phase III study (JACOB) [abstract]. J Clin Oncol 2013(suppl 31):TPS4150. http://www.asco.org/.

28. LoRusso PM, Weiss D, Guardino E, Girish S, Sliwkowski MX: Trastuzumab emtansine: a unique antibody-drug conjugate in development for human epidermal growth factor receptor 2-positive cancer. Clin Cancer Res 2011, 17(20):6437-6447.

29. Kim JG: Molecular targeted therapy for advanced gastric cancer. Korean J Intern Med 2013, 28(2):149-155.

30. Bang Y: A randomized, open-label, phase III study of lapatinib in combination with weekly paclitaxel versus weekly paclitaxel alone in the second-line treatment of HER2 amplified advanced gastric cancer (AGC) in Asian population: Tytan study [abstract]. J Clin Oncol 2012(suppl 34):11. http://www.asco.org/.

31. Hecht JR, Bang Y, Qin S, Chung H, Xu J, Park J, Jeziorski K, Shparyk Y, Hoff PM, Sobrero AF, et al: Lapatinib in combination with capecitabine plus oxaliplatin in HER2-positive advanced or metastatic gastric, esophageal, or gastroesophageal adenocarcinoma: The TRIO-013/LOGiC Trial [abstract]. J Clin Oncol 2013(Suppl 31):LBA4001. http://www.asco.org/.

32. Han SW, Oh DY, Im SA, Park SR, Lee KW, Song HS, Lee NS, Lee KH, Choi IS, Lee $\mathrm{MH}$, et al: Phase II study and biomarker analysis of cetuximab combined with modifi ed FOLFOX6 in advanced gastric cancer. Br J Cancer 2009, 100(2):298-304

33. Moehler M, Mueller A, Trarbach T, Lordick F, Seufferlein T, Kubicka S, Geissler M, Schwarz S, Galle PR, Kanzler S: German Arbeitsgemeinschaft Internistische Onkologie. Cetuximab with irinotecan, folinic acid and 5-fl uorouracil as fi rst-line treatment in advanced gastroesophageal cancer: a prospective multi-center biomarker-oriented phase II study. Ann Oncol 2011, 22(6):1358-1366.
34. Lordick F, Luber B, Lorenzen S, Hegewisch-Becker S, Folprecht G, Wöll E, Decker T, Endlicher E, Röthling N, Schuster T, et al: Cetuximab plus oxaliplatin/leucovorin/5-fl uorouracil in first-line metastatic gastric cancer: a phase II study of the Arbeitsgemeinschaft Internistische Onkologie (AIO). Br J Cancer 2010, 102(3):500-505

35. Kim C, Lee JL, Ryu MH, Chang HM, Kim TW, Lim HY, Kang HJ, Park YS, Ryoo BY, Kang YK: A prospective phase II study of cetuximab in combination with XELOX (capecitabine and oxaliplatin) in patients with metastatic and/or recurrent advanced gastric cancer. Invest New Drugs 2011, 29(2):366-373.

36. Lordick F, Kang YK, Chung HC, Salman P, Oh SC, Bodoky G, Kurteva G, Volovat C, Moiseyenko VM, Gorbunova V, et al: Capecitabine and cisplatin with or without cetuximab for patients with previously untreated advanced gastric cancer (EXPAND): a randomised, open-label phase 3 trial. Lancet Oncol 2013, 14(6):490-499.

37. Waddell T, Chau I, Cunningham D, Gonzalez D, Okines AF, Okines C, Wotherspoon A, Saffery C, Middleton G, Wadsley J, et al: Epirubicin, oxaliplatin, and capecitabine with or without panitumumab for patients with previously untreated advanced oesophagogastric cancer (REAL3): a randomised, open-label phase 3 trial. Lancet Oncol 2013, 14(6):481-489.

38. Ferrara N, Gerber HP, LeCouter J: The biology of VEGF and its receptors. Nat Med 2003, 9(6):669-676.

39. Gerber HP, Ferrara N: Pharmacology and pharmacodynamics of bevacizumab as monotherapy or in combination with cytotoxic therapy in preclinical studies. Cancer Res 2005, 65(3):671-680.

40. Kim SE, Shim KN, Jung SA, Yoo K, Lee JH: The clinicopathological significance of tissue levels of hypoxia-inducible factor-1alpha and vascular endothelial growth factor in gastric cancer. Gut Liver 2009, 3(2):88-94.

41. Maeda K, Chung YS, Ogawa Y, Takatsuka S, Kang SM, Ogawa M, Sawada T, Sowa M: Prognostic value of vascular endothelial growth factor expression in gastric carcinoma. Cancer 1996, 77(5):858-863.

42. Song ZJ, Gong P, Wu YE: Relationship between the expression of iNOS, VEGF, tumor angiogenesis and gastric cancer. World J Gastroenterol 2002, 8(4):591-595.

43. Shah MA, Ramanathan RK, Ilson DH, Levnor A, D'Adamo D, O'Reilly E, Tse A, Trocola R, Schwartz L, Capanu M, et al: Multicenter phase II study of irinotecan, cisplatin, and bevacizumab in patients with metastatic gastric or gastroesophageal junction adenocarcinoma. J Clin Oncol 2006, 24(33):5201-5206.

44. Shah MA, Jhawer M, Ilson DH, Lefkowitz RA, Robinson E, Capanu M, Kelsen DP: Phase II study of modified docetaxel, cisplatin, and fluorouracil with bevacizumab in patients with metastatic gastroesophageal adenocarcinoma. J Clin Oncol 2011, 29(7):868-874.

45. El-Rayes BF, Zalupski M, Bekai-Saab T, Heilbrun LK, Hammad N, Patel B, Urba S, Shields AF, Vaishampayan U, Dawson S, et al: A phase II study of bevacizumab, oxaliplatin, and docetaxel in locally advanced and metastatic gastric and gastroesophageal junction cancers. Ann Oncol 2010, 21(10):1999-2004.

46. Ohtsu A, Shah MA, Van Cutsem E, Rha SY, Sawaki A, Park SR, Lim HY, Yamada $Y$, Wu J, Langer B, et al: Bevacizumab in combination with chemotherapy as first-line therapy in advanced gastric cancer: a randomized, double-blind, placebo-controlled phase III study. J Clin Oncol 2011, 29(30):3968-3976.

47. Spratlin JL, Cohen RB, Eadens M, Gore L, Camidge DR, Diab S, Leong S, O'Bryant C, Chow LQ, Serkova NJ, et al: Phase I pharmacologic and biologic study of ramucirumab (IMC-1121B), a fully human immunoglobulin G1 monoclonal antibody targeting the vascular endothelial growth factor receptor-2. J Clin Oncol 2010, 28(5):780-787.

48. Fuchs CS, Tomasek J, Cho JY, Dumitru F, Passalacqua R, Goswami C, Safran H, Dos Santos LV, Aprile G, Ferry DR, et al: REGARD: A phase III, randomized, double-blinded trial of ramucirumab and best supportive care (BSC) versus placebo and BSC in the treatment of metastatic gastric or gastroesophageal junction (GEJ) adenocarcinoma following disease progression on first-line platinum- and/or fluoropyrimidine-containing combination therapy [abstract]. J Clin Oncol 2012(suppl 34):LBA5. http://www.asco.org/.

49. Tian S, Quan H, Xie C, Guo H, Lü F, Xu Y, Li J, Lou L: YN968D1 is a novel and selective inhibitor of vascular endothelial growth factor receptor-2 tyrosine kinase with potent activity in vitro and in vivo. Cancer Sci 2011, 102(7):1374-1380. 
50. Li J, Qin S, Xu J, Guo WJ, Xiong JP, Bai Y, Sun G, Yang Y, Wang L, Xu $N$, et al: A randomized, double-blind, multicenter, phase, three-arm, placebo-control study of apatinib as third-line treatment in patients with metastatic gastric carcinoma [abstract]. J Clin Oncol 2011 29(Suppl):4019.

51. Sharma T, Dhingra R, Singh S, Sharma S, Tomar P, Malhotra M, Bhardwaj TR: Aflibercept: a novel VEGF targeted agent to explore the future perspectives of anti-angiogenic therapy for the treatment of multiple tumors. Mini Rev Med Chem 2013, 13(4):530-540.

52. Holash J, Davis S, Papadopoulos N, Croll SD, Ho L, Russell M, Boland P, Leidich R, Hylton D, Burova E, et al: VEGFTrap: a VEGF blocker with potent antitumor effects. Proc Natl Acad Sci USA 2002, 99(17):11393-11398.

53. Konner J, Dupont J: Use of soluble recombinant decoy VEGF trap to inhibit VEGF activity. Clin Colorectal Cancer 2004, 4:S81-S85.

54. Lassoued W, Murphy D, Tsai J, Oueslati R, Thurston G, Lee WM: Effect of VEGF and VEGF Trap on vascular endothelial cell signaling in tumors. Cancer Biol Ther 2011, 10(12):1326-1333.

55. Maulik G, Shrikhande A, Kijima T, Ma PC, Morrison PT, Salgia R: Role of the hepatocyte growth factor receptor, c-Met, in oncogenesis and potential for therapeutic inhibition. Cytokine Growth Factor Rev 2002, 13(1):41.

56. Galland F, Stefanova M, Lafage M, Birnbaum D: Localization of the 5'end of the MCF2 oncogene to human chromosome $15 q 15 \rightarrow$ q23. Cytogenet Genome Res 1992, 60(2):114-116.

57. Comoglio PM, Giordano S, Trusolino L: Drug development of MET inhibitors: targeting oncogene addiction and expedience. Nat Rev Drug Discov 2008, 7(6):504-516.

58. Nakajima M, Sawada H, Yamada Y, Watanabe A, Tatsumi M, Yamashita J, Matsuda M, Sakaguchi T, Hirao T, Nakano H, et al: The prognostic significance of amplification and overexpression of c-met and c-erb B-2 in human gastric carcinomas. Cancer 1999, 85(9):1894-1902.

59. Dussault I, Bellon SF: From concept to reality: the long road to c-Met and RON receptor tyrosine kinase inhibitors for the treatment of cancer. AntiCancer Agents Med Chem 2009, 9(2):221-229.

60. Eathiraj S, Palma R, Volckova E, Hirschi M, France DS, Ashwell MA, Chan TC: Discovery of a novel mode of protein kinase inhibition characterized by the mechanism of inhibition of human mesenchymal-epithelial transition factor (c-Met) protein autophosphorylation by ARQ 197. J Biol Chem 2011, 286(23):20666-20676.

61. Underiner TL, Herbertz T, Miknyoczki SJ: Discovery of small molecule c-Met inhibitors: evolution and profiles of clinical candidates. Anti-Cancer Agents Med Chem 2010, 10(1):7.

62. Choueiri TK, Vaishampayan U, Rosenberg JE, Logan TF, Harzstark AL, Bukowski RM, Rini BI, Srinivas S, Stein MN, Adams LM, et al: Phase II and biomarker study of the dual MET/VEGFR2inhibitor foretinib in patients with papillary renal cell carcinoma. J Clin Oncol 2013, 31(2):181-186.

63. Muro K, Ryu MH, Yasui H, Nishina T, Ryoo BY, Boku N, Kang YK: A phase II study of tivantinib monotherapy in patients with previously treated advanced or recurrent gastric cancer [abstract]. J Clin Oncol 2012 (suppl):4082. http://www.asco.org/.

64. Bjornsti MA, Houghton PJ: The TOR pathway: a target for cancer therapy. Nat Rev Cancer 2004, 4(5):335-348.

65. Martín ME, MI P' r, Redondo C, Alvarez MI, Salinas M, Fando JL: 4E binding protein 1 expression is inversely correlated to the progression of gastrointestinal cancers. Int J Biochem Cell Biol 2000 32(6):633-642

66. Cejka D, Preusser M, Woehrer A, Sieghart W, Strommer S, Werzowa J, Fuereder T, Wacheck V: Everolimus (RAD001) and anti-angiogenic cyclophosphamide show long-term control of gastric cancer growth in vivo. Cancer Biol Ther 2008, 7(9):1377-1385.

67. Okamoto I, Doi T, Ohtsu A, Miyazaki M, Tsuya A, Kurei K, Kobayashi K, Nakagawa K: Phase I clinical and pharmacokinetic study of RAD001 (Everolimus) administered daily to Japanese patients with advanced solid tumors. Jpn J Clin Oncol 2010, 40(1):17-23.
68. Doi T, Muro K, Boku N, Yamada Y, Nishina T, Takiuchi H, Komatsu Y, Hamamoto Y, Ohno N, Fujita Y, et al: Multicenter phase II study of everolimus in patients with previously treated metastatic gastric cancer. J Clin Oncol 2010, 28(11):1904-1910.

69. Van Cutsem E, Yeh KH, Bang YJ, et al: Phase III trial of everolimus (EVE) in previously treated patients with advanced gastric cancer (AGC): GRANITE-1[abstract]. J Clin Oncol 2012(Suppl 4):LBA3. http://www.asco.org/.

doi:10.1186/2050-7771-1-32

Cite this article as: Qiu and Xu: The progress of targeted therapy in advanced gastric cancer. Biomarker Research 2013 1:32.

\section{Submit your next manuscript to BioMed Central and take full advantage of:}

- Convenient online submission

- Thorough peer review

- No space constraints or color figure charges

- Immediate publication on acceptance

- Inclusion in PubMed, CAS, Scopus and Google Scholar

- Research which is freely available for redistribution

Submit your manuscript at www.biomedcentral.com/submit
C) Biomed Central 